\title{
Pengembangan Modul Struktur Atom Berbasis Guided Discovery Learning untuk Kelas X SMA
}

\author{
Yondriadi $^{1}$ and Yerimadesi ${ }^{*}$ \\ ${ }^{1}$ Pendidikan Kimia, Universitas Negeri Padang, Jl. Prof. Dr. Hamka Air Tawar Barat, \\ Padang Utara, Sumatera Barat 25171, Indonesia \\ *yeri@fmipa.unp.ac.id
}

\begin{abstract}
This research is aimed at developing a atomic structure module based on guided discovery learning for grade X SMA and determining the level of validity and practicality. The type of research used is Research and Development (R\&D). The development model used is Plomp model which consists of 3 stages, namely: 1) preliminary research, 2) prototyping stage, and 3) assessment phase. The validity test of this module was done by two chemistry lecturers at FMIPA UNP, two chemistry teachers at SMAN 3 Pariaman, and a chemistry teachers at SMAN 4 Pariaman using validation instrument. Practicality test was done by 2 chemistry teachers at SMAN 3 Pariaman and 34 students X MIPA 1 of SMAN 3 Pariaman using practicality questionnaires. Validity instrument and practicality questionnaires were analized by Cohen Kappa (k) Formula. The results of the analysis of the validity with an average score of the kappa moment 0.86 which is very high category of validity. The results of teachers practice analysis, and the practicality of students show the average score of the moment of kappa (k) in a row is 0.90 which is a very high practicality category and 0.84 which is also a very high practicality category. The data obtained shows that the atomic structure module based on guided discovery learning for grade X SMA produced is valid and practical.
\end{abstract}

\section{Pendahuluan}

Konsep struktur atom merupakan salah satu konsep kimia yang dipelajari oleh peserta didik Sekolah Menengah Atas (SMA). Umumnya peserta didik cenderung belajar dengan cara hafalan, daripada secara aktif mencari untuk membangun pemahaman mereka sendiri terhadap konsep tersebut. Untuk dapat memahami konsep-konsep dalam kimia diperlukan pemahaman yang benar terhadap konsep dasar yang membangun konsep tersebut. Untuk itu sangat diperlukan suatu kondisi belajar bermakna agar menjadikan peserta didik dapat memahami konsep struktur atom tersebut [1].

Dalam pembelajaran struktur atom ditemui beberapa kesulitan yang dialami oleh peserta didik antara lain; (1) peserta didik kesulitan dalam menggambarkan model atom yang dikemukakan oleh beberapa ahli; (2) peserta didik kesulitan dalam menentukan konfigurasi elektron dan elektron valensi dari suatu atom; (3) peserta didik kesulitan untuk menentukan atau membedakan isotop, isobar dan isoton [2]. Tingkat pencapaian konsepsi peserta didik pada materi struktur atom yaitu sebesar 37,03\% peserta didik pada kelompok tahu konsep, 28,91\% peserta didik pada kelompok tidak tahu konsep, dan 34,06\% peserta didik pada kelompok miskonsepsi [3].

Berdasarkan hasil wawancara guru dan pengisian angket oleh peserta didik di SMAN 2 Pariaman dan SMAN 3 Pariaman diperoleh hasil; (1) materi struktur atom masih kurang dipahami oleh beberapa orang peserta didik; (2) bahan ajar yang digunakan di sekolah adalah buku cetak, dan lembar kerja peserta didik; (3) kurang pahamnya peserta didik belajar secara mandiri dengan bahan ajar yang digunakan tanpa bimbingan dari guru. Dalam proses pembelajaran, salah satu komponen penting yang menunjang keberhasilan peserta didik dalam belajar adalah bahan ajar yang dipilih dan dikembangkan guru. Bahan ajar yang sesuai dapat menunjang tercapainya tujuan pembelajaran dengan cara memotivasi peserta didik untuk lebih aktif dan giat dalam belajar melalui materi yang disajikan. 
Kemampuan pemecahan masalah kimia merupakan indikator keberhasilan dalam pembelajaran. Penggunaan metode pembelajaran konvensional tidak diperbolehkan dalam pengajaran sains, dan kimia tertentu [4]. Salah satu usaha yang dapat dilakukan guru untuk mengatasi kesulitan belajar peserta didik adalah dengan menyiapkan media, bahan ajar dan membimbing peserta didik dalam proses pembelajaran. Selain media pembelajaran, guru juga dituntut untuk menyiapkan bahan ajar yang dapat menuntun peserta didik untuk belajar, seperti LKS, handout, dan modul [5].

Beberapa peneliti telah melakukan penelitian bahwa penggunaan modul dalam pembelajaran kimia dapat meningkatkan hasil belajar peserta didik. Diantaranya penggunaan modul larutan penyangga berbasis discovery learning efektif terhadap hasil belajar peserta didik kelas XI MIA di SMAN 7 Padang dimana hasil belajar kognitif peserta didik yang menggunakan modul lebih tinggi daripada peserta didik yang belajar dengan tanpa modul [6]; modul larutan penyangga dengan model inquiry terbukti efektif dalam meningkatkan pemahaman konsep dan keterampilan generik sains peserta didik[7]; modul koloid berbasis problem-based learning dapat meningkatkan kemampuan berpikir kritis peserta didik [8]; modul ikatan kimia berbasis scientific approach efektif meningkatkan prestasi belajar peserta didik dari aspek pengetahuan, sikap dan keterampilan peserta didik [9]. Dengan menggunakan modul dapat merangsang motivasi intrinsik peserta didik untuk belajar kimia, motivasi intrinsik peserta didik yang belajar kimia dengan menggunakan modul lebih tinggi secara signifikan dibandingkan dengan pembelajaran tanpa modul [10].

Pada kurikulum 2013 peserta didik dituntut untuk aktif dan mandiri dalam mencari, mengolah, mengkonstruksi dan menggunakan pengetahuannya. Metode pembelajaran yang berpusat pada peserta didik dengan memperkuat rasa partisipasi kelompok di antara peserta didik memotivasi mereka untuk belajar lebih lanjut dan meningkatkan pembelajaran di tingkat kognisi yang lebih tinggi [11]. Untuk memperoleh kemampuan pemecahan masalah kimia yang baik, perlu diterapkan model pembelajaran yang dapat membimbing peserta didik dalam mengkonstruksikan pemikiran sehingga peserta didik mampu menemukan konsep untuk pemecahan permasalahan yang ada. Penerapan model pembelajaran guided discovery learning efektif terhadap kemampuan pemecahan masalah kimia [12].

Model pembelajaran penemuan terbimbing memberikan pengaruh yang signifikan terhadap kemampuan keterampilan berpikir kritis peserta didik pada pembelajaran biologi [13]; merangsang peserta didik berpikir kreatif dan membantu peserta didik dalam menemukan pengetahuan atau konsep baru matematika [14]; suasana pembelajaran lebih menyenangkan dan lebih menantang peserta didik dalam menemukan konsep-konsep sendiri serta peserta didik mampu melatih keterampilan proses sains [15]. Penerapan model guided discovery learning pada pembelajaran kimia berpengaruh positif terhadap hasil belajar baik aspek kognitif, afektif, dan psikomotorik peserta didik [16].

\section{Metode}

Jenis penelitian ini adalah penelitian dan pengembangan atau Research and Development (R\&D). Model pengembangan yang digunakan dalam penelitian ini adalah model Plomp yang dikembangkan oleh Tjeerd Plomp. Model ini terdiri dari 3 tahap, yaitu (1) preliminary research, (2) prototyping stage, dan (3) assessment phase [17]. Subjek penelitian ini adalah dua orang dosen kimia FMIPA UNP, tiga orang guru kimia, dan 34 orang peserta didik kelas X MIPA SMAN 3 Pariaman.

Tujuan tahap investigasi awal (preliminary research) adalah untuk menentukan dan mendefinisikan syarat-syarat yang dibutuhkan dalam penelitian pengembangan modul struktur atom berbasis guided discovery learning untuk kelas X SMA. Tahap ini meliputi: (a) analisis kebutuhan dilakukan dengan wawancara guru dan angket peserta didik untuk melihat gambaran kondisi di lapangan yang berkaitan dengan proses pembelajaran kimia pada materi struktur atom di sekolah; (b) analisis kurikulum dilakukan dengan menelaah kurikulum yang digunakan pada sekolah uji coba yaitu kurikulum 2013 revisi 2018. Analisis ini berupa analisis Kompetensi dasar (KD) dan bahan materi pembelajaran dimana dalam silabus dituliskan bahwa materi struktur atom pada KD 3.2 dan 4.2. Berdasarkan KD tersebut, dapat dirumuskan indikator pencapaian kompetensi dan tujuan pembelajaran pada materi struktur atom; (c) studi literatur pada tahap ini dilakukan pencarian sumber dan referensi yang berhubungan dengan kegiatan penelitian. Sumber dan referensi dapat berupa buku, jurnal maupun sumber dari internet; (d) pengembangan kerangka konseptual dilakukan dengan cara pengidentifikasian, perincian dan penyusunan konsep-konsep utama yang dipelajari yaitu materi struktur atom. Selanjutnya, dilakukan 
penyusunan terhadap konsep tersebut dalam bentuk tabel analisis konsep dan memudahkan dalam penyusunan peta konsep.

Tahap pembentukan prototipe (prototyping stage), disusun rancangan modul struktur atom berbasis guided discovery learning sebagai prototipe I. Kemudian dilakukan beberapa evaluasi formatif pada setiap prototipe yang dihasilkan. Evaluasi formatif dimulai dengan evaluasi diri sendiri (self evaluation) berdasarkan daftar cek (checklist) dari karakteristik atau spesifikasi desain. Tahap selanjutya adalah penilaian ahli (expert review) dengan memberikan penilaian dan saran terhadap produk yang dikembangkan. Penilaian ahli dilakukan dengan menggunakan angket validitas kepada lima orang validator yang ahli dibidang pengembangan modul kimia. Setelah dilakukan penilaian ahli, dilakukan uji coba satu satu (one to one evaluation) yaitu meminta masukan mengenai produk yang dikembangkan melalui lembar wawancara kepada tiga orang peserta didik yang memiliki tingkat kemampuan berbeda (tinggi, sedang, dan rendah). Selanjutnya dilakukan uji kelompok kecil (small group evaluation) yaitu memberikan angket praktikalitas kepada enam orang peserta didik dengan tingkat kemampuan berbeda. Dan terakhir adalah uji lapangan (field test), untuk mengukur praktikalitas produk yang dikembangkan. Uji lapangan dilakukan dengan penilaian angket praktikalitas berdasarkan respon guru dan peserta didik.

Tahap penilaian (assessment phase). Pada tahap penilaian dilakukan evaluasi untuk menyimpulkan apakah produk yang dihasilkan dapat digunakan dalam prakteknya dilapangan. Jika diperlukan revisi terhadap prototipe IV maka dilakukan revisi sesuai dengan saran dari dosen pembimbing.

Instrumen yang digunakan adalah angket validitas dan praktikalitas. Lembar validitas digunakan untuk menilai validitas modul struktur atom berbasis guided discovery learning yang dikembangkan. Lembar validitas ini ditujukan kepada dosen kimia FMIPA UNP dan guru kimia. Lembar praktikalitas digunakan untuk mengetahui tingkat praktikalitas pemakaian modul struktur atom berbasis guided discovery learning yang dikembangkan. Lembar praktikalitas ini ditujukan kepada guru kimia dan peserta didik.

Data yang diperoleh dianalisis menggunakan formula kappa Cohen di bawah ini.

$$
\text { momen kappa }(\kappa)=\frac{\rho_{0}-\rho_{\varepsilon}}{1-\rho_{\varepsilon}}
$$

$\kappa=$ momen kappa, $\rho_{o}=$ proporsi yang terealisasi, $\rho_{\theta}=$ proporsi yang tidak terealisasi

Tabel 1. Kategori Keputusan berdasarkan Momen Kappa [18]

\begin{tabular}{c|c} 
Interval & Kategori \\
\hline $0,81-1,00$ & Sangat tinggi \\
\hline $0,61-0,80$ & Tinggi \\
\hline $0,41-0,60$ & Sedang \\
\hline $0,21-0,40$ & Rendah \\
\hline $0,01-0,20$ & Sangat rendah \\
\hline$<0,00$ & Tidak valid
\end{tabular}

\section{Hasil dan Diskusi}

\subsection{Preliminary research}

3.1.1. Analisis kebutuhan. Melalui observasi yang telah dilakukan di SMAN 2 Pariaman dan SMAN 3 Pariaman diketahui bahwa belum tersedia bahan ajar dalam bentuk modul yang sesuai dengan tuntutan Kurikulum 2013 di sekolah, khususnya modul struktur atom berbasis guided discovery learning.

3.1.2. Analisis kurikulum. Analisis terhadap silabus pada Kurikulum 2013 revisi 2018 yang telah dilakukan berupa analisis Kompetensi Dasar (KD) yang dijabarkan menjadi beberapa Indikator Pencapaian Kompetensi (IPK). Kompetensi dasar pada materi struktur atom adalah sebagai berikut ini. 
Tabel 2. Kompetensi Dasar dan Indikator Pencapaian Kompetensi

\begin{tabular}{|c|c|}
\hline Kompetensi Dasar dari KI-3 & Kompetensi Dasar dari KI-4 \\
\hline $\begin{array}{l}\text { 3.2. Menganalisis perkembangan model } \\
\text { atom dari model atom Dalton, Thomson, } \\
\text { Rutherfod, Bohr, dan Mekanika Gelom- } \\
\text { bang. }\end{array}$ & $\begin{array}{l}\text { 4.2. Menjelaskan fenomena alam atau } \\
\text { hasil percobaan menggunakan model } \\
\text { atom. }\end{array}$ \\
\hline $\begin{array}{c}\text { Indikator Pencapaian Kompetensi } \\
\text { (Pengetahuan) }\end{array}$ & $\begin{array}{c}\text { Indikator Pencapaian Kompetensi } \\
\text { (Keterampilan) }\end{array}$ \\
\hline $\begin{array}{l}\text { 3.2.1. Menyimpulkan model atom } \\
\text { Dalton. } \\
\text { 3.2.2. Menyimpulkan model atom } \\
\text { Thomson } \\
\text { 3.2.3. Menyimpulkan model atom } \\
\text { Rutherford. } \\
\text { 3.2.4. Menyimpulkan model atom Bohr. } \\
\text { 3.2.5. Menyimpulkan model atom } \\
\text { mekanika gelombang. } \\
\text { 3.2.6. Menganalisis partikel dasar } \\
\text { penyusun atom. } \\
\text { 3.2.7. Menganalisis perbedaan nomor } \\
\text { atom dan nomor massa suatu atom } \\
\text { dengan jumlah partikel dasar penyusun } \\
\text { atom. } \\
\text { 3.2.8. Menganalisis perbedaan isotop, } \\
\text { isobar dan isoton (melalui jumlah proton, } \\
\text { elektron dan neutron dari suatu unsur). }\end{array}$ & $\begin{array}{l}\text { 4.2.1. Menjelaskan model atom Dalton } \\
\text { berdasarkan fenomena alam atau hasil } \\
\text { percobaan. } \\
\text { 4.2.2. Menjelaskan model atom } \\
\text { Thomson dan Rutherford berdasarkan } \\
\text { fenomena alam atau hasil percobaan. } \\
\text { 4.2.3. Menjelaskan model atom Bohr } \\
\text { berdasarkan fenomena alam atau hasil } \\
\text { percobaan. } \\
\text { 4.2.4. Menjelaskan model atom } \\
\text { mekanika gelombang berdasarkan } \\
\text { fenomena alam atau hasil percobaan. }\end{array}$ \\
\hline
\end{tabular}

3.1.3. Studi literatur. Pada tahap studi literatur dilakukan pencarian sumber dan referensi yang berhubungan dengan kegiatan penelitian. (1) komponen modul terdiri dari cover [19], petunjuk penggunaan modul, kompetensi yang akan dicapai, [20], peta konsep, lembar kegiatan (motivation and problem presentation, data collection, data processing, verification, dan closure [21], lembaran kerja, kunci lembaran kerja, soal eveluasi, dan kunci jawaban evaluasi [22]. (2) model pengembangan dalam penelitian ini yaitu model Plomp oleh Tjeerd Plomp, model Plomp dinyatakan lebih cocok dikarenakan pada setiap langkahnya memuat kegiatan pengembangan yang dapat disesuaikan dengan karateristik penelitiannya [24]. (3) Sumber dan referensi konsep struktur atom berupa buku kimia universitas dan buku kimia SMA seperti Brady J. E. Jespersen [25].

3.1.4. Pengembangan kerangka konseptual. Berdasarkan analisis konsep yang telah dilakukan, diperoleh hasil bahwa konsep-konsep utama yang harus dikuasai peserta didik antara lain: model atom Dalton, model atom Thomson, model atom Rutherford, model atom Bohr, model atom mekanika gelombang, partikel dasar penyusun atom, nomor atom dan nomor massa, serta isotop, isobar dan isoton. Konsep-konsep utama tersebut diperoleh dari buku kimia universitas dan buku kimia SMA. Sehingga peta konsep dapat disusun secara hirarki.

\subsection{Prototyping stage}

3.2.1. Prototype I. Tahap ini dilakukan desain modul (komponen model dapat dilihat pada studi literatur) sehingga dihasilkan Prototipe I berupa modul struktur atom berbasis guided discovery learning untuk kelas X SMA.

3.2.2. Prototype II. Berdasarkan hasil evaluasi diri sendiri, diketahui bahwa prototipe I membutuhkan revisi pada bagian atau komponen yang tidak sesuai dengan tahapan guided discovery learning. Revisi 
yang dilakukan akan menghasilkan prototiipe II.

3.2.3. Prototype III. Prototipe III merupakan prototipe yang dihasilkan dari revisi yang dilakukan pada prototipe II. Setelah prototipe II terbentuk, maka pada tahap ini dilakukan evaluasi formatif berupa penilaian dari ahli (expert review) dan uji coba satu satu (one to one evaluation).

3.2.3.1. Expert review. Penilaian ahli (expert review) bertujuan untuk mendapatkan prototipe yang valid secara keilmuan. Validitas modul struktur atom berbasis guided discovery learning dilakukan oleh lima orang validator yang terdiri dari dua orang dosen Jurusan Kimia FMIPA UNP, dua orang guru kimia SMAN 3 Pariaman, dan seorang guru kimia SMAN 4 Pariaman. Hal ini sejalan dengan pendapat yang dikembangkan oleh Sugiyono (2013) bahwa untuk menguji validitas instrument, dapat digunakan pendapat ahli (judgment experts) yang jumlah minimalnya yaitu tiga orang. Penilaian yang diberikan oleh validator dianalisis dengan menggunakan formula kappa cohen untuk memperoleh momen kappa. Momen kappa menunjukkan validitas suatu produk. Hasil analisis data validitas dapat dilihat pada Tabel 3.

Tabel 3. Hasil Validitas Modul oleh Lima Orang Validator

\begin{tabular}{c|c|c} 
Aspek yang dinilai & $\mathbf{\kappa}$ & Kategori \\
\hline Kelayakan isi & 0,81 & Sangat tinggi \\
\hline Kebahasaan & 0,90 & Sangat tinggi \\
\hline Penyajian & 0,89 & Sangat tinggi \\
\hline Kegrafisan & 0,84 & Sangat tinggi \\
\hline K validitas & $\mathbf{0 , 8 6}$ & Sangat tinggi
\end{tabular}

3.2.3.1.1. Validitas isi. Validitas isi modul struktur atom berbasis guided discovery learning memiliki momen kappa (k) sebesar 0,81 dengan kategori validitas sangat tinggi yang menunjukkan bahwa materi yang terdapat pada modul telah sesuai dengan kurikulum yang berlaku (kurikulum 2013 revisi 2018) yang meliputi tuntutan Kompenternsi Inti (KI) dan Indikator Pencapaian Kompetensi (IPK). Hal ini sesuai dengan Rochmad (2012) menyatakan untuk menghasilkan sebuah modul yang bermakna dan dapat dengan mudah digunakan oleh peserta didik maka modul harus menggambarkan kompetensi dasar, indikator pencapaian kompetensi, yang akan dicapai oleh peserta didik.

3.2.3.1.2. Validitas kebahasaan. Penilaian validitas komponen kebahasaan pada modul struktur atom berbasis guided discovery learning memiliki kategori validitas sangat tinggi dengan nilai momen kappa sebesar 0,90. Hal ini menunjukkan modul yang telah dikembangkan menggunakan bentuk dan ukuran huruf yang dapat dibaca, petunjuk dan informasi yang disampaikan pada modul jelas, modul menggunakan kaidah Bahasa Indonesia yang baik dan bahasa yang dapat dipahami.

3.2.3.1.3. Validitas penyajian. Validitas penyajian terhadap modul struktur atom berbasis guided discovery learning memiliki momen kappa (k) sebesar 0,89 dengan kategori validitas sangat tinggi. Hal ini menunjukkan bahwa komponen-komponen yang ada di dalam modul telah di sajikan secara baik dan tidak bertentangan satu sama lain. Hal ini sesuai dengan pendapat Rochmad (2012) bahwa validasi konstruk digunakan untuk memeriksa apakah komponen model yang satu tidak bertentangan dengan komponen model yang lainnya.

3.2.3.1.4. Validitas kegrafisan. Validitas kegrafisan dengan modul struktur atom berbasis guided discovery learning memiliki nilai momen kappa $(\mathrm{k})$ sebesar 0,84 dengan kategori validitas sangat tinggi. Hasil analisis tingkat kevalidan dari produk pengembangan, secara keseluruhan memiliki nilai rata-rata hasil uji validitas modul struktur atom berbasis guided discovery learning yaitu 0,86 dengan kategori validitas sangat tinggi. Hal ini membuktikan bahwa modul yang dibuat telah sesuai dengan keempat aspek dalam uji validitas, sehingga modul ini dapat digunakan sebagai bahan ajar dalam proses pembelajaran kimia pada materi struktur atom.

Berdasarkan analisis data hasil validitas terhadap prototipe II diketahui bahwa prototipe yang 
dihasilkan memiliki tingkat validitas yang sangat tinggi dengan momen kappa 0.86. Akan tetapi, walaupun prototipe II telah menunjukan tingkat validitas yang sangat tinggi, masih ada bagian-bagian modul yang harus diperbaiki.

3.2.3.2. One to one evaluation. Uji coba satu-satu dilakukan terhadap tiga orang peserta didik kelas $\mathrm{X}$ SMAN 3 Pariaman yang telah mempelajari materi struktur atom. Berdasarkan hasil wawancara yang dilakukan pada uji coba satu-satu diperoleh kesimpulan dari tiga orang peserta didik bahwa, model guided discovery learning yang disajikan di dalam modul dapat membantu peserta didik dalam menjawab pertanyaan pada prototipe II. Penggunaan bahasa yang digunakan di dalam modul dapat dipahami oleh peserta didik, selain itu, untuk penggunaan huruf, simbol dan desain gambar pada modul dapat membuat peserta didik tertarik dan bersemangat untuk mempelajarinya sedangkan tampilan warna modul, peserta didik menyarankan untuk memilih warna yang tidak terlalu gelap sehingga dilakukan revisi terhadap warna tampilan tesebut.

3.2.4. Prototype IV. Hasil praktikalitas yang didapatkan pada uji coba kelompok kecil (small group evaluation) untuk mengungkap tingkat praktikalitas kemudahan penggunaan, efisiensi waktu pembelajaran, dan manfaat dari prototipe III yang dihasilkan. Hasil uji coba kelompok kecil (small group evaluation) dapat dilihat pada Tabel 4.

Tabel 4. Hasil Praktikalitas Modul pada Small Group Evaluation

\begin{tabular}{c|c|c} 
Aspek yang dinilai & $\mathbf{\kappa}$ & Kategori \\
\hline Kemudahan penggunaan & 0,82 & Sangat tinggi \\
\hline Efesiensi waktu belajar & 0,90 & Sangat tinggi \\
\hline Manfaat & 0,84 & Sangat tinggi \\
\hline K praktikalitas & $\mathbf{0 , 8 5}$ & Sangat tinggi
\end{tabular}

Berdasarkan hasil analisis data praktikalitas yang diberikan oleh enam orang peserta didik kelas $\mathrm{X}$ pada uji coba kelompok kecil (small group evaluation) terhadap prototipe III didapatkan rata-rata momen kappa seluruh komponen praktikalitas yaitu 0,85 dengan kategori kepraktisan yang sangat tinggi. Akan tetapi, walaupun prototipe III telah menunjukkan kepraktisan yang tinggi, masih ada bagian-bagian pada modul yang harus diperbaiki. Revisi yang dilakukan akan menghasilkan prototipe IV.

\subsection{Assessment phase.}

Tahap penilaian dilakukan dengan praktikalitas uji lapangan (field test) terhadap prototipe IV yang telah dihasilkan untuk mengetahui kategori kepraktisan dari prototipe. Berdasarkan pengolahan data lembar penilaian angket respon guru dan siswa diperoleh hasil analisis data seperti yang terdapat pada Tabel 5.

Tabel 5. Hasil Praktikalitas Modul pada Field Test oleh Guru dan Peserta Didik

\begin{tabular}{c|c|c|c|c}
\multirow{2}{*}{ Aspek yang dinilai } & \multicolumn{2}{|c|}{ Guru } & \multicolumn{2}{c}{ Peserta didik } \\
\cline { 2 - 5 } & $\mathbf{\kappa}$ & Kategori & $\boldsymbol{\kappa}$ & Kategori \\
\hline Kemudahan penggunaan & 0,89 & Sangat tinggi & 0,82 & Sangat tinggi \\
\hline Efesiensi waktu belajar & 0,93 & Sangat tinggi & 0,86 & Sangat tinggi \\
\hline Manfaat & 0,87 & Sangat tinggi & 0,83 & Sangat tinggi \\
\hline к praktikalitas & $\mathbf{0 , 9 0}$ & Sangat tinggi & $\mathbf{0 , 8 4}$ & Sangat tinggi
\end{tabular}

Berdasarkan hasil analisis data praktikalitas dari dua orang guru kimia di SMAN 3 Pariaman didapatkan rata-rata momen kappa dari ketiga aspek yang dinilai yaitu 0,90 dengan kategori praktikalitas yang sangat tinggi dan hasil analisis data praktikalitas dari 34 orang siswa kelas X MIPA SMAN 3 Pariaman didapatkan rata-rata momen kappa dari ketiga aspek yang dinilai yaitu 0,84 dengan kategori praktikalitas yang sangat tinggi. 


\section{Simpulan}

Berdasarkan hasil penelitian dan pengembangan modul struktur atom berbasis guided discovery learning untuk kelas X SMA maka dapat disimpulkan bahwa: Modul struktur atom berbasis guided discovery learning dapat dikembangkan dengan model pengembangan Plomp yang terdiri dari 3 tahap yaitu tahap penelitian pendahuluan (preliminary research), tahap pengembangan (prototyping stage), dan tahap penelitian (assessment phase). Modul struktur atom berbasis guided discovery learning untuk kelas X SMA yang dihasilkan mempunyai tingkat validitas dan praktikalitas yang sangat tinggi.

\section{Referensi}

[1] Arifin, S. 2014. Meningkatkan Aktivitas Belajar dan Pemahaman Siswa dalam Pembelajaran Struktur Atom Melalui Strategi Peta Konsep dengan Penulisan Jurnal Belajar Pada Kelas X-2 SMA Negeri 2 Tanjung. Quantum. Jurnal Inovasi Pendidikan Sains, Volume 5, Nomor 1, Halaman 47-56.

[2] Harahap, S.N. 2016. Pengembangan Model Pembelajaran dengan Mengintegrasikan Strategi Pembelajaran dan Media Pembelajaran pada Pokok Bahasan Struktur Atom. Jurnal Pendidikan Kimia, Volume 8 Nomor 1, Halaman 19-26.

[3] A'yun, Q., Harjito, dan Murbangun, N. 2018. Analisis Miskonsepsi Siswa Menggunakan Tes Diagnostic Multiple Choice Berbantuan Cri (Certainty of Response Index). Jurnal Inovasi Pendidikan Kimia, Volume 12, Nomor 1, Halaman 2108-2117.

[4] Akani, O. 2017. Effect of Guided Discovery Method of Instruction and Students' Achievement in Chemistry at the Secondary School Level in Nigeria. Omiko Akani IJSRE. Volume 5, Nomor 2, Halaman 6226-6234.

[5] Yerimadesi, Bayharti, dan Risa, O. 2018. Validitas dan Praktikalitas Modul Reaksi Redoks dan Sel Elektrokimia Berbasis Guided Discovery Learning untuk SMA. Jurnal Eksakta Pendidikan (JEP). Volume 2, Nomor 1, Halaman 17-24.

[6] Yerimadesi, Ananda, P., dan Ririanti. (2017). Efektivitas Penggunaan Modul Larutan Penyangga Berbasis Discovery Learning terhadap Hasil Belajar Siswa Kelas XI MIA SMAN 7 Padang. Jurnal Eksakta Pendidikan (JEP). Volume 1, Nomor 1, Halaman 17-23.

[7] Septiani, D., Woro, S., dan Saptorini. 2014. Efektivitas Model Inkuiri Berbantuan Modul dalam Meningkatkan Pemahaman Konsep dan Keterampilan Generik Sains. Jurnal Inovasi Pendidikan Kimia. Volume 8, Nomor 2, Halaman 1340-1350.

[8] Pratama G.W., Ashadi, A., dan Nurma, Y.I. 2017. Efektivitas Penggunaan Modul Pembelajaran Kimia Berbasis Problem-Based Learning (PBL) untuk Meningkatkan Kemampuan Berpikir Kritis Siswa pada Materi Koloid SMA Kelas XI. Prosiding Seminar Nasional Pendidikan Sains (SNPS), Halaman 150-156.

[9] Astuti, D.R., Sulistyo, S., dan Sri, M. 2016. Pengembangan Modul Kimia Berbasis Scientific Approach pada Materi Ikatan Kimia Kelas X SMA/MA Semester 1. Jurnal Inkuiri. Volume 5, Nomor 2, Halaman 71-78.

[10] Vaino, K., Jack, H., and Miia, R. 2012. Stimulating Students' Intrinsic Motivation for Learning Chemistry Through the Use of Context-Based Learning Modules. Chemistry Education Research and Practice. Volume 13, Halaman 410-419.

[11] Makoolati, N., M. Amini, H. Raisi, Sh. Yazdani, and A.V. Razeghi. 2015. The Effectiveness of Guided Discovery Learning on the Learning and Satisfaction of Nursing Students. Hormozgan Medical Journal. Volume 8, Nomor 6, Halaman 490-496.

[12] Sulistyowati, N., Antonius, T.W., dan Woro, S. 2012. Efektivitas Model Pembelajaran Guided Discovery Learning Terhadap Kemampuan Pemecahan Masalah Kimia. Chem in Edu. Volume 2, Nomor 1, Halaman 49-55.

[13] Widura, H.S., Puguh, K., dan Joko, A. 2015. Pengaruh Model Guided Discovery Learning terhadap Kemampuan Berpikir Kritis Siswa Kelas X SMA Negeri 8 Surakarta Tahun Pelajaran 2014/2015. Bio-Pedagogi. Volume 4, Nomor 2, Halaman 25-30. 
[14] Jayanto, I.F., dan Sri, H.N. 2017. Kemampuan Berpikir Kreatif dengan Pembelajaran Guided Discovery. Prosiding Seminar Nasional Matematika dan Pendidikan Matematika UIN Raden Intan Lampung, Halaman 245-255.

[15] Rosidi, I. 2016. Pengembangan Lembar Kegiatan Siswa Berorientasi Pembelajaran Penemuan Terbimbing (Guided Discovery Learning) untuk Melatihkan Keterampilan Proses Sains. Jurnal Pena Sains. Volume 3, Nomor 1, Halaman 55-63.

[16] Handayani, C.F., Wisnu, S., dan Sri, S.S. 2017. Penerapan Model Pembelajaran Guided Discovery Melalui Kegiatan Praktikum pada Materi Stoikiometri Larutan. Jurnal Inovasi Pendidikan Kimia. Volume 11, Nomor 1, Halaman 1840-1848.

[17] Plomp, T. and Nieveen, N. 2013. Education Design Research, Ensschede Netherland: National Institute for Curriculum Development (SLO).

[18] Boslaugh, S., and Paul, A.W. 2008. Statistics In a Nutshell, a desktop quickreference. Beijing, Cambridge, Famham, Koln, Sebastopol, Taipe, Tokyo: O'reilly.

[19] Prastowo, A. 2011. Panduan Membuat Bahan Ajar Inovatif: Menciptakan Metode Pembelajaran Yang Menarik dan Menyenangkan. Yogyakarta: DIVA Press

[20] Depdiknas. 2008. Panduan Pengembangan Bahan Ajar. Jakarta: Departemen Pendidikan Nasional.

[21] Yerimadesi, dkk. 2017. Model Guided Discovery Learning untuk Pembelajaran Kimia (GDLPK). Padang: UNP Press.

[22] Suryosubroto. 1983. Sitem Pengajaran Dengan Modul. Jakarta: Bina Aksara.

[23] Sugiyono. 2013. Metode Penelitian Kombinasi (Mixed Methods). Bandung: Alfabeta.

[24] Rochmad. 2012. Desain Model Pengembangan Perangkat Pembelajaran Matematika. Jurnal kreano. Volume 3, Nomor 1, Halaman 59-72.

[25] Brady, J. E., Jespersen, N. D. and Hyslop, A. 2010. Chemistry The Molecular Nature of Matter 6th edition. John Wiley and Sons, Inc. 